\title{
ОТВЕТСТВЕННОСТЬ ЗА НАРУШЕНИЕ ФИНАНСОВОГО ЗАКОНОААТЕАЬСТВА: УГОЛОВНО-ПРАВОВАЯ И КРИМИНОЛОГИЧЕСКАЯ ХАРАКТЕРИСТИКИ ПРЕСТУПАЕНИЙ, СОВЕРШАЕМЫХ В ФИНАНСОВОЙ СФЕРЕ
}

\author{
Н.М. Артемов, Л.Л. Арзуманова, О.В. Болтинова, С.Я. Саламова, А.А. Ситник, Чо Ын Джин \\ Московский государственный юридический университет им. О.Е. Кутафина (МГЮА), г. Москва, \\ Российская Федерация
}

Информация о статье

Дата поступления

5 мая 2017 г.

Дата принятия в печать 27 ноября 2017 г.

Дата онлайн-размещения 15 декабря 2017 г.

\section{Ключевые слова}

Финансы; бюджетная сфера; уголовная ответственность в финансовой сфере; денежное обращение; экономические преступления бухгалтерских документов

\begin{abstract}
Аннотация. Анализ уголовной политики в экономической сфере как основного направления и средства воздействия на преступность позволяет выделить в доктрине различные ее направления, такие как криминологическое и уголовноправовое. Авторы предлагаемой статьи обращают особое внимание на одно из направлений в реализации уголовной политики Российской Федерации - преступления в сфере экономической деятельности. Особо подчеркиваются гарантии государства в области единства экономического пространства, свободного перемещения товаров, услуг и финансовых средств, поддержки конкуренции, свободы экономической деятельности. В этой связи требуется эффективное решение задач государственной экономической политики, составной частью которой признается финансовая политика государства, что предполагает создание и поддержание благоприятного делового климата, формирование условий для ведения бизнеса посредством стимулирования законной предпринимательской деятельности. С другой стороны, отмечается рост числа совершаемых в рассматриваемой сфере преступлений в области бюджетного, налогового законодательства, денежного обращения, валютного регулирования и т.п. Делается заключение, что преступления в финансовой сфере носят сложный и комплексный характер, требующий проведения исследований в области доктринального и законодательного регламентирования финансово-правовых норм, нашедших свое отражение в таких элементах, как бюджетное, налоговое законодательство, сферы денежного и валютного регулирования, банковской и страховой деятельности, рынка ценных бумаг, а также децентрализованных финансов. Противодействие преступной деятельности в финансовой сфере должно прежде всего реализовываться посредством применения комплекса мер политического, экономического, социального, организационного и правового характера, благодаря которым возможно принятие эффективных норм, устанавливающих ответственность за нарушение финансового законодательства, и точное и единообразное применение составов преступлений, имеющих финансовую направленность и отличающихся высоким уровнем сложности.
\end{abstract}

\section{LIABILITY FOR VIOLATING FINANCIAL LEGISLATION: CRIMINAL LAW AND CRIMINOLOGICAL CHARACTERISTICS OF FINANCIAL CRIMES}

\author{
Nikolai M. Artemov, Lana L. Arzumanova, Olga V. Boltinova, Sebila Ya. Salamova, \\ Aleksandr A. Sitnik, Cho Eun Jin \\ Kutafin Moscow State Law University (MSAL), Moscow, the Russian Federation
}

\author{
Article info \\ Received \\ 2017 May 5 \\ Accepted \\ 2017 November 27 \\ Available online \\ 2017 December 15

\section{Keywords} \\ Finance; public sector; criminal liability \\ in the financial sector; monetary \\ circulation; economic crimes
}

\begin{abstract}
The analysis of criminal policy in the economic sphere as the dominant way and measure of influencing crime allows the authors to single out the criminological and the criminal law trends of its doctrine. They pay special attention to one of the areas of criminal policy's implementation in the Russian Federation - economic crimes. The authors also stress state guarantees of the integrity of economic area, free movement of goods, services and financial assets, support of competition, freedom of economic activities. This demands an effective solution of state economic policy's tasks, including state financial policy, which requires the creation and support of a favorable business climate and conditions by encouraging lawful entrepreneurial activities. On the other hand, there is an increase in the number of crimes that violate budgetary and tax legislation, monetary circulation, currency regulation, etc. The authors come to the conclusion that financial crimes have a complex character and require the research of doctrinal and legislative regulation of financial law norms reflected in budgetary and tax legislation, monetary and
\end{abstract}


currency regulation, banking and insurance activities, securities market and decentralized finance. Counteraction to financial crimes should be primarily carried out through the implementation of a complex of political, economic, social, organizational and legal measures that will make it possible to adopt effective norms determining liability for the violations of financial legislation and to use precise and uniform definitions of sophisticated financial crimes.

Общая характеристика ответственности за нарушение финансового законодательства. Конституция Российской Федерации гарантирует единство экономического пространства, свободу перемещения финансовых средств, защиту частной собственности, свободу предпринимательской деятельности (ст. 8, 34 и 35 Конституции РФ) ${ }^{1}$.

Совершенствование экономического развития в настоящее время рассматривается в качестве одного из наиболее приоритетных направлений государственной политики [1, с. 135; 2; 3]. В свою очередь, решение задач государственной экономической политики (частью которой является финансовая) возможно лишь в условиях создания и поддержания благоприятного делового предпринимательского и инвестиционного климата, а также при наличии действенных организационно-правовых механизмов, позволяющих исключить возможность использования уголовного преследования в качестве средства давления на предпринимательские структуры и решения споров хозяйствующих субъектов. К данному выводу, в частности, пришел Пленум Верховного Суда РФ в своем постановлении от 15 ноября 2016 г. № $48^{2}$.

Решение поставленной цели позволит снизить количество правонарушений и преступлений в экономической сфере и на ее отдельном направлении - финансовом.

Декларативность заявлений Верховного Суда РФ можно признать своевременной, поскольку в течение последних лет в Российской Федерации был предпринят целый ряд мер, направленных на модернизацию системы управления публичными финансами. В частности, Правительство Российской Федерации сделало достаточно шагов на пути преобразования процесса прогнозирования и внедрения в практику государственного управления среднесрочного и долгосрочного планирования.

В отличие от большинства видов экономических отношений, именно финансовым при-

${ }^{1}$ Конституция Российской Федерации : принята всенар. голосованием 12 дек. 1993 г. (в ред. от 21 авг. 2014 г.) // Российская газета. 1993. 25 дек.

${ }^{2}$ Бюллетень Верховного Суда РФ. 2017. № 1. сущ публичный характер, поскольку одной из их сторон выступает властный субъект - государство - в лице уполномоченных органов государственной власти и местного самоуправления. Кроме того, в отличие от традиционных экономических отношений, финансовые (костяк этих отношений) носят безвозмездный характер и исключают получение встречного удовлетворения в виде прибыли или иной материальной выгоды управомоченным субъектом в процессе формирования, распределения и использования финансовых потоков.

В настоящее время государство реализует новые подходы к формированию основных направлений бюджетной и налоговой политики, проведению финансового контроля, осуществлению среднесрочного и долгосрочного бюджетного планирования, нацеленных на реализацию концепции бюджетирования, ориентированного на результат. Указанные мероприятия имеют своей целью повышение стабильности финансовой системы государства, эффективности расходования бюджетных средств, а также ответственности за использование средств налогоплательщиков.

Финансовые отношения в настоящее время урегулированы блоком бюджетного и налогового законодательства, нормативными актами в сфере валютного и банковского регулирования и контроля (надзора), страхового законодательства и т.п. Однако в последние годы прослеживается тенденция нарушения норм финансового законодательства в области бюджетной и налоговой деятельности, денежного обращения и валютного регулирования, а также в других сферах финансовой деятельности государства и муниципальных образований.

Финансовое правонарушение по своему характеру, содержанию, формам и способам проявления относится к числу сложных юридических категорий и выступает составной частью правового поведения в сфере финансовой деятельности государства. За нарушения в области финансов установлена ответственность нормами таких отраслей права, как финансовое, административное и уголовное. В свою очередь, 
финансовые преступления считаются разновидностью экономических общественно опасных посягательств и находятся с ними в отношении части и целого.

K специфическим особенностям финансовых преступлений, на основании которых производится их отграничение от иных групп экономических преступлений, можно отнести следующие:

- преступная деятельность субъекта связана с образованием, распределением и использованием финансов. В первую очередь это касается централизованных и децентрализованных денежных фондов государства и муниципальных образований. К финансовым преступлениям также следует отнести общественно опасные деяния, которые напрямую не связаны с образованием и использованием фондов публичноправовых образований, но влияют на стабильность финансовой системы;

- экономическая деятельность в подавляющем большинстве случаев подконтрольна органам власти, а в отдельных случаях - управомоченным физическим и юридическим лицам. В то же время финансовой преступности присуща высокая латентность;

- отношения между субъектами финансовых правоотношений строятся на принципе власти подчинения, реже - на односторонних правах и обязанностях гражданско-правового характера;

- субъектами финансовых преступлений являются участники финансовых правоотношений, права и обязанности которых определяются финансовым законодательством Российской Федерации. Именно за нарушение соответствующих финансовых обязанностей и наступает уголовная ответственность.

Таким образом, под финансовым преступлением можно понимать общественно опасное деяние, совершаемое субъектами финансовых правоотношений в процессе образования, распределения (перераспределения), использования и контроля за использованием централизованных и децентрализованных фондов государства и муниципальных образований, а также влияющее на стабильность и эффективность функционирования финансовой системы Российской Федерации.

Виды финансовых преступлений. Как отмечается в науке, «финансовые преступления крайне многообразны и сложны. В зависимости от обстоятельств криминалистическое значение могут иметь различные факторы и целесообраз- ны различные варианты классификации» [1]. Руководствуясь данным положением, можно провести классификацию финансовых преступлений по различным основаниям. Так, по сфере посягательств выделяют преступления в сфере:

- налогообложения;

- рынка ценных бумаг;

- страхового рынка;

- валютного рынка;

- межбанковского денежного рынка;

- кредитного рынка;

- рынка товаров и услуг [2].

По объекту преступных посягательств рассматривают преступления, посягающие:

- на финансовую систему государства;

- финансы иных хозяйствующих субъектов (предприятий и организаций).

В доктрине можно встретить и другую точку зрения на данный вопрос. В частности, Ю.В. Трунцевский придерживается мнения, что наиболее правильной является классификация финансовых преступлений, проводимая не по объекту, а «с учетом использования субъектами экономических отношений при совершении преступлений финансовых механизмов как средства достижения желаемого результата». Исходя из этого, финансовые преступления подразделяются указанным автором на следующие виды:

- преступления, посягающие на государственные финансы и финансовый контроль (ст. 159, 160, 171.1, 176 (ч. 2), 194, 198-199.2, 285.1, 285.2, 287, 325 (ч. 3), 327.1);

- преступления, посягающие на банковскую систему (ст. 172, 174, 174.1, 191);

- преступления, посягающие на безопасность финансовой (банковской, налоговой) системы, добросовестную конкуренцию в данной сфере (ст. 183);

- преступления, посягающие на денежное обращение (ст. 181, 185, 185.1, 186-188, 191-193);

- преступления, посягающие на кредитную систему (ст. 176, 177);

- преступления, посягающие на банковскую, налоговую и кредитную системы (ст. 173);

- преступления, посягающие на налоговую и кредитную системы (ст. 195);

- финансовое мошенничество (ст. 159) [3].

В то же время при применении данной классификации необходимо иметь в виду следующее:

- некоторые из вышеперечисленных статей утратили юридическую силу. В частности, это касается ст. 173 УК РФ «Лжепредпринимательство»; 
- с момента, когда была предложена данная классификация, уголовное законодательство было дополнено новыми составами. Так, ряд общественно опасных деяний, связанных с мошенничеством, был выделен в отдельные статьи УК РФ. При этом в большинстве случаев квалифицированные составы мошенничества связаны с преступными действиями в финансовой сфере: ст. 159.1 («Мошенничество в сфере кредитования»), ст. 159.2 («Мошенничество при получении выплат»), ст. 159.3 («Мошенничество с использованием платежных карт») и т.д.;

- приведенная классификация проведена не по одному основанию. Например, по мнению автора, преступление, закрепленное в ст. 173 УК РФ, посягает на банковскую, налоговую и кредитную системы, а ст. 195 УК РФ - на налоговую и кредитную системы. Таким образом, ст. 173 могла бы входить во вторую группу.

Кроме того, следует иметь в виду, что с точки зрения теории финансового права финансовая система - общее понятие, включающее в себя бюджетную, налоговую, банковскую систему и т.д. Таким образом, все указанные преступления фактически наносят ущерб финансовой системе государства.

Исходя из этого, можно предложить следующую классификацию финансовых преступлений:

- преступления в бюджетной сфере, т.е. преступления, затрагивающие вопросы расходования бюджетов бюджетной системы (например, ст. 185.1 и 185.2 УК РФ ${ }^{3}$ );

- преступления, связанные с невыполнением обязанностей по уплате обязательных платежей, в том числе налоговые преступления и преступления, связанные с невыполнением обязанностей по уплате иных обязательных платежей (в частности, таможенных платежей) (ст. 194, 198-199.2 УК РФ и т.д.);

- преступления в сфере денежного обращения, т.е. затрагивающие вопросы обращения национальной и иностранной валюты в наличной и безналичной форме (например, ст. 174, 174.1, 186, 187, 193 и т.д.);

- преступления в сфере финансового рынка, т.е. связанные с оказанием финансовых услуг (159.1, 159.3, 170.1, 172.1, 177 УК РФ и т.д.).

Общая характеристика состояния финансовой преступности. Четко охарактеризовать нынешнее состояние финансовой преступности сложно. Одной из причин этого является отсут-

3 Собрание законодательства РФ. 1996. № 25. Ст. 2954. ствие статистической отчетности по преступности в финансовой сфере. В ежегодном статистическом сборнике Главного информационного центра МВД России ${ }^{4}$ представлено количество преступлений экономической направленности, часть которых составляют преступления в сфере финансов. Другие источники статистической информации МВД России указывают количество преступлений, совершенных в сфере экономики и связанных в том числе с финансовой деятельностью. Ярким примером тому служат данные МВД России.

Так, согласно имеющейся статистической информации за январь - август 2017 г., всего было зарегистрировано 1 378,9 тыс. преступлений, из них 37,7 \% - преступления против собственности, 32,9 \% - преступления в сфере экономической деятельности, 13,5 \% - преступления против государственной власти, интересов государственной службы и службы в органах местного самоуправления, 1,9 \% - преступления против интересов службы в коммерческих организациях, 14,0 \% - прочие преступления ${ }^{5}$. Категория преступлений, о которых идет речь в настоящей статье, относится к числу "прочих». Тем не менее приводимые показатели не дают единого, а главное, объективного представления о том, какое именно число преступлений совершается непосредственно в финансовой сфере.

Можно говорить, что уголовная политика современного периода в данной области является крайне непоследовательной и неэффективной. Одновременно с включением в разд. VIII УК РФ новых норм об экономических преступлениях, относимых к категории преступлений небольшой или средней тяжести, были приняты нормы о специальных видах освобождения от уголовной ответственности за экономические преступления при условии соблюдения важного критерия - возмещения причиненного ущерба.

Официальные данные свидетельствуют о ежегодном снижении количества преступлений в сфере экономической деятельности. В частности, согласно статистической информации МВД, в 2016 г. было зарегистрировано 108,8 тыс. преступлений экономической направленности, в 2015 г. - 112,4 тыс., в 2014 г. - 107,3 тыс., в 2013 г. - 141,2 тыс. $^{6}$ Подобная тенденция кос-

4 Преступность и правонарушения (2011-2015) : стат. сб. М., 2016. 180 с.

${ }^{5}$ URL: https://мвд.рф/folder/101762/item/11233840.

${ }^{6}$ Там же. 
венно свидетельствует о снижении преступности в финансовой сфере, однако действительной причиной уменьшения числа преступлений является упразднение правоохранительных структур, специализирующихся в обеспечении национальной безопасности в области экономики, а также снижение качества принимаемых уголовно-правовых норм о преступлениях в сфере экономической деятельности, что, в свою очередь, не позволяет надлежащим образом осуществлять реализацию уголовной ответственности.

Говоря об эффективности противодействия финансовой преступности в целом, признать ее удовлетворительной, к сожалению, не представляется возможным, что отчасти подтверждается данными, демонстрирующими устойчивый рост дефицита федерального бюджета - с 0,042 трлн р. в 2012 г. до 2,36 трлн р. в 2016 г.

Следует отметить, что за первое полугодие 2017 г. было выявлено 66460 преступлений экономической направленности, из них связано с финансово-кредитной системой - 9197 преступлений, освоением бюджетных средств - 4 642, внешнеэкономической деятельностью - 908, государственным заказом - 469 преступлений.

Применительно к конкретным видам преступлений следует отметить, что в рассматриваемый период было выявлено:

- изготовление или сбыт поддельных денег или ценных бумаг - 10307 преступлений;

- уклонение от уплаты налогов и (или) сборов с физического лица - 385 преступлений;

- уклонение от уплаты налогов и (или) сборов с организации - 1164 преступления;

- злоупотребление полномочиями 490 преступлений.

Превалирование преступлений, связанных с изготовлением или сбытом поддельных денег или ценных бумаг, обусловливается тем, что в качестве преступления регистрируется каждый факт выявления фальшивой купюры (реже ценной бумаги). Такие преступления легче выявить, в отличие от налоговых преступлений. Кроме того, необходимо иметь в виду, что в качестве налоговых преступлений рассматривается общественно опасное деяние, совершенное в крупном размере, фальшивомонетничество вне зависимости от ущерба.

Наконец, рассматривая распределение зарегистрированных экономических преступлений по федеральным округам, следует отметить, что в Центральном федеральном округе было зарегистрировано 28 \% таких преступлений, в
Северо-Западном - 10 \%, Южном - $9 \%$, Cеверо-Кавказском - 4 \%, Приволжском - $21 \%$, Уральском - 11 \%, Дальневосточном - 4 \%, Сибирском - 13 \%. Таким образом, доминирующими по показателям экономической преступности являются два федеральных округа Центральный (28 \%) и Приволжский (21\%).

В то же время, оценивая официальную статистику, следует принять во внимание еще одну особенность, присущую экономической, и в частности финансовой, преступности, - ее высокую латентность. Причины этого многообразны и порой носят как объективный, так и субъективный характер. На показатели финансовой преступности существенное влияние оказывают следующие субъективные факторы: наличие политической воли; активизация или ослабление борьбы с данным видом преступлений; нацеленность оперативных аппаратов на их выявление; уровень подготовки и профессиональной компетентности работников правоохранительных органов, занимающихся расследованием преступлений, и др.

Отдельные составы финансовых преступлений. Представив общую характеристику преступлений, совершаемых в финансово-правовой сфере, перейдем к непосредственному анализу некоторых составов, устанавливающих ответственность за нарушение законодательных требований в бюджетной, налоговой, денежнокредитной и валютной сферах. При этом условием исследования станет анализ законодательных актов, устанавливающих ответственность как за правонарушения, так и за преступления в указанной сфере. Отметим, однако, что в силу обширности вопроса, ставшего предметом изучения, в рамках настоящей статьи ставится задача уделить внимание лишь некоторым составам преступлений в сфере финансовой деятельности. Особо подчеркнем, что исследования в представленной области знаний ведутся хаотично: в рамках изучения отдельных институтов финансовой ответственности, в форме самостоятельных исследований ответственности за нарушение установленных законодательством правил денежного обращения [4], ответственности за нарушение валютного законодательства [5-7] и ответственности в области легализации преступных доходов [8].

Однако прежде следует ответить на вопрос: что есть ответственность в финансово-правовой сфере? Характеризуя понятие ответственности, в целом можно говорить о том, что это публич- 
ный правовой механизм воздействия государства на субъектов, нарушающих законодательные требования.

Традиционно ответственность в финансово-правовой сфере подразделяют на финансово-правовую и за нарушение законодательства в финансовой сфере. Последняя при этом рассматривается шире и включает составы правонарушений, установленных не только в отраслевом законодательстве (например, БК $\mathrm{P}^{7}, \mathrm{HK}$ Р $\left.\Phi^{8}\right)$, но и в других нормативных правовых актах (КоАП Р $\Phi^{9}$, УК $\left.Р \Phi^{10}\right)$.

Также представляется возможным подразделить ответственность, исходя из отраслевого признака, на финансовую, административную, уголовную и т.п. Следует отметить, что вопрос о выделении финансовой ответственности в самостоятельный вид юридической ответственности в настоящее время носит дискуссионный характер.

В то же время очевидно, что разграничение ответственности по видам не может совпадать с отраслевой структурой права [9, с. 46]. Например, административная ответственность может наступать за нарушение норм административного, финансового, конституционного и иных отраслей российского права. Материальную и дисциплинарную ответственность также не следует рассматривать как виды ответственности, характерные исключительно для трудового права. Из этого можно сделать несколько выводов. Во-первых, наличие собственного вида ответственности не является критическим фактором для признания той или иной отрасли самостоятельной. Во-вторых, административная и уголовная ответственность направлены на охрану общественных отношений, складывающихся в различных отраслях российского права, в том числе в финансовой.

Главным критерием разграничения противоправных деяний в финансовой сфере прежде всего является субъект ответственности. В качестве примера можно привести правонарушения (в том числе преступления) в бюджетной сфере. Так, если в случае с нецелевым использованием бюджетных средств виновным признается участник бюджетного процесса, то его необходимо привлечь к ответственности по ст. 306.4 БК

\footnotetext{
7 Собрание законодательства РФ. 1998. № 31.
} Ст. 3823.

\footnotetext{
${ }^{8}$ Там же. Ст. 3824 ; 2000. № 32. Ст. 3340.

${ }^{9}$ Там же. 2002. № 1, ч. 1. Ст. 1.

${ }^{10}$ Там же. 1996. № 25. Ст. 2954.
}

РФ. Вместе с тем должностные лица при наличии оснований могут быть привлечены к административной ответственности уже по ст. 15.14 КоАП РФ или к уголовной ответственности по ст. 285.1 УК РФ («Нецелевое расходование бюджетных средств»).

Действующее бюджетное законодательство содержит перечень видов бюджетных нарушений и бюджетных мер принуждения. В частности, за нарушение бюджетного законодательства могут применяться меры:

- административной ответственности (ст. 15.14, 15.15 КоАП РФ);

- уголовной ответственности (ст. 285.1, 285.2 УК РФ).

Одним из видов бюджетных нарушений, установленных в БК РФ, является нецелевое использование бюджетных средств (ст. 306.4 БК РФ). По данным Счетной палаты Российской Федерации, в ходе контрольных мероприятий в 2016 г. объем выявленных бюджетных средств, которые содержали признаки нецелевого использования, составил 1,1 млрд . $^{11}$ Для сравнения: в 2015 г. аналогичный показатель был равен 3,7 млрд р. ${ }^{12}$, а в 2014 г. - 9,1 млрд р. ${ }^{13}$ Приведенные цифры четко свидетельствуют о тенденции снижения количества бюджетных средств, расходуемых нецелевым образом. В первую очередь это обусловлено установлением новых правил осуществления госзакупок, изменением порядка проведения внутреннего бюджетного контроля, повышением прозрачности расходования бюджетных средств, а также принятием иных мер, нацеленных на усиление финансовой дисциплины в бюджетной сфере.

Нецелевое использование бюджетных средств, исходя из содержания ст. 306.4 БК РФ, выражается в направлении указанных денежных средств, а также в оплате денежных обязательств в целях, которые не соответствуют целям (полностью или частично), определенным документом, который является правовым основанием предоставления указанных средств. В качестве такого документа может выступать

11 Отчет о работе Счетной палаты Российской Федерации в 2016 г. URL: http://www.ach.gov.ru/activities/ annual_report/\#896.

12 Отчет о работе Счетной палаты Российской Федерации в 2015 г. URL: http://www.ach.gov.ru/activities/ annual_report/\#874.

13 Отчет о работе Счетной палаты Российской Федерации в 2014 г. URL: http://www.ach.gov.ru/activities/ annual_report/\#842.7. 
как бюджет (закон или решение), так и сводная бюджетная роспись, бюджетная смета и т.д.

Уголовная ответственность за нецелевое использование бюджетных средств была введена Федеральным законом «О внесении изменений и дополнений в Уголовный кодекс Российской Федерации» от 8 декабря 2003 г. № $162-\Phi 3^{14}$.

В соответствии со ст. 285.1 УК РФ нецелевое расходование бюджетных средств представляет собой их расходование должностным лицом получателя бюджетных средств на цели, не соответствующие условиям их получения, определенным утвержденными бюджетом, бюджетной росписью, уведомлением о бюджетных ассигнованиях, сметой доходов и расходов либо иным документом, являющимся основанием для получения бюджетных средств.

Рассматриваемое преступление считается оконченным с момента нецелевого расходования бюджетных средств. В отношении должностных лиц, помимо размера ущерба, должна применяться и степень общественной опасности последствий и действий.

Исследование правоприменительной практики и доктринальных источников в сфере уголовного права позволяет заключить, что хищение бюджетных средств, совершаемое должностным лицом путем мошенничества, как правило, заключается в списании денежных сумм с лицевого счета учреждения в пользу иных физических лиц или организаций, состоящих в сговоре с указанным должностным лицом, за поставленные ими товары, выполненные работы или оказанные услуги.

Кроме того, необходимо отграничивать нецелевое расходование бюджетных средств от их хищения в форме присвоения или растраты (ст. 160 УК РФ), в основе которого учитывается наличие или отсутствие корыстной цели и иные признаки, характеризующие данную форму хищения.

Еще одной крупной группой финансовых преступлений являются преступления в сфере денежного обращения. Криминализация сферы денежного обращения наиболее опасна для современного общества, поскольку денежная система неразрывно связана с другими элементами финансовой системы государства. В указанную группу входят преступления, закрепленные:

14 Собрание законодательства РФ. 2003. № 50. Ст. 4848.
- ст. 174 УК РФ («Легализация (отмывание) денежных средств или иного имущества, приобретенных другими лицами преступным путем»);

- ст. 174.1 УК РФ («Легализация (отмывание) денежных средств или иного имущества, приобретенных лицом в результате совершения им преступления»);

- ст. 186 УК РФ («Изготовление, хранение, перевозка или сбыт поддельных денег или ценных бумаг»);

- ст. 187 УК РФ («Неправомерный оборот средств платежей»);

- ст. 193 УК РФ («Уклонение от исполнения обязанностей по репатриации денежных средств в иностранной валюте или валюте Российской Федерации»);

- ст. 200.1 УК РФ («Контрабанда наличных денежных средств и (или) денежных инструментов»).

Одним из наиболее общественно опасных деяний в финансовой сфере является легализация (отмывание) денежных средств или иного имущества, приобретенных другими лицами преступным путем. В соответствии с п. 3 Федерального закона «О противодействии легализации (отмыванию) доходов, полученных преступным путем, и финансированию терроризма» от 7 августа 2001 г. № 115-Ф315 под легализацией (отмыванием) доходов, полученных преступным путем, следует понимать придание правомерного вида владению, пользованию или распоряжению денежными средствами или иным имуществом, полученными в результате совершения преступления. Следует подчеркнуть, что, как правило, процесс легализации носит длительный, системный характер. Легализация (отмывание) денежных средств или иного имущества, добытых преступным путем, создает основу для теневой экономики, причиняет вред экономической безопасности и финансовой стабильности государства [10].

Уголовная ответственность за совершение преступлений в сфере легализации (отмывания) доходов, полученных преступным путем, устанавливается ст. 174 и 174.1 УК РФ.

Объективная сторона преступления, закрепленного в ч. 1 ст. 174 УК РФ, заключается в совершении финансовых операций и других сделок с денежными средствами или иным имуществом, заведомо приобретенными другими лицами преступным путем, в це-

\footnotetext{
${ }^{15}$ Собрание законодательства РФ. 2001. № 33, ч. 1.
} СТ. 3418. 
лях придания правомерного вида владению, пользованию и распоряжению указанными денежными средствами или иным имуществом. Следовательно, субъектом данного преступления является посредник, помогающий лииу, которое приобрело денежные средства и иное имущество в результате ранее совершенного преступления, придать правомерный вид владению, пользованию и распоряжению данным имуществом.

В соответствии с разъяснениями Верховного Суда РФ под финансовыми операциями и другими сделками, указанными в ст. 174 и 174.1 УК РФ, следует понимать действия с денежными средствами, ценными бумагами и иным имуществом (независимо от формы и способа их осуществления, например договор займа или кредита, банковский вклад, обращение с деньгами и управление ими в задействованном хозяйственном проекте), направленные на установление, изменение или прекращение связанных с ними гражданских прав или обязанностей ${ }^{16}$.

При этом для квалификации соответствующих действий в качестве преступления по ст. 174 УК РФ необходимо точно установить, что лицу было известно о том, что имущество было приобретено преступным путем.

Квалифицированные составы рассматриваемого преступления связаны с совершением того же деяния в крупном размере (ч. 2 ст. 174 УК РФ), группой лиц по предварительному сговору или лицом с использованием своего служебного положения (пп. «а» и «б»ч. 3 ст. 174 УК РФ), организованной группой или в особо крупном размере (пп. «а» и «б» ч. 4 ст. 174 УК РФ).

В свою очередь, согласно ч. 1 ст. 174.1 УК РФ, уголовная ответственность наступает также за совершение финансовых операций и других сделок с денежными средствами или иным имуществом, приобретенными лицом в результате совершения им преступления, в целях придания правомерного вида владению, пользованию и распоряжению указанными денежными средствами или иным имуществом. Таким образом, субъектом данного преступления будет выступать лицо, которое приобрело денежные

16 О судебной практике по делам о незаконном предпринимательстве и легализации (отмывании) денежных средств или иного имущества, приобретенных преступным путем : постановление Пленума Верхов. Суда РФ от 18 нояб. 2004 г. № 23. Пункты 19, 20 // Бюллетень Верховного Суда РФ. 2005. № 1. средства или иное имущество в результате совершенного ранее преступления (преступник по другому преступлению).

Следует отметить, что ч. 2-4 ст. 174.1 УК РФ предусматривают те же квалифицирующие признаки, что и ч. 2-4 ст. 174 УК РФ соответственно.

В России правовой плацдарм противодействия нелегальному обороту преступных доходов составляют нормы Конституции РФ и Федеральный закон «О противодействии легализации (отмыванию) доходов, полученных преступным путем, и финансированию терроризма» от 7 августа 2001 г. № $115-Ф 3^{17}$.

К числу международных актов, в которых установлены меры по предупреждению транснациональной легализации (отмывания) денежных средств или иного имущества, добытых преступным путем, относятся:

- Конвенция ООН о борьбе против незаконного оборота наркотических средств и психотропных веществ (Вена, 20 декабря 1988 г.);

- Конвенция ООН об отмывании, выявлении, изъятии и конфискации доходов от преступной деятельности (Страсбург, 8 ноября 1990 г.);

- Конвенция ООН об уголовной ответственности за коррупцию (Страсбург, 27 января 1999 г.);

- Конвенция ООН против транснациональной организованной преступности (принята в Нью-Йорке 15 ноября 2000 г. Резолюцией 55/25 на 62-м пленарном заседании 55-й сессии Генеральной Ассамблеи ООН);

- Конвенция ООН против коррупции (принята в Нью-Йорке 31 октября 2003 г. Резолюцией 58/4 на 51-м пленарном заседании 58-й сессии Генеральной Ассамблеи ООН).

Также активно используются документы, выпущенные Группой разработки финансовых мер борьбы с отмыванием денег (ФАТФ).

В настоящее время валютный режим Российской Федерации характеризуется наличием системы валютных ограничений, которые направлены на лимитирование и запрет совершения некоторых видов валютных операций, а также на установление дополнительных обязанностей для субъектов валютных правоотношений. Одной из основных валютных операций является репатриация валюты: резидент обязан обеспечить зачисление на счета, открытые в уполномоченных банках, национальной и иностранной валюты, причитающейся ему по внешнеторговому контракту. Обязанность по Ст. 3418 . 
репатриации валюты устанавливается ст. 19 Федерального закона «О валютном регулировании и валютном контроле» от 10 декабря 2003 г. № 173-Ф3 ${ }^{18}$, ответственность за невыполнение данной обязанности - ч. 4, 4.1, 5 ст. 15.25 КоАП РФ и ст. 193 УК РФ.

Уголовная ответственность наступает за нерепатриацию валюты от одного или нескольких нерезидентов в крупном размере (ч. 1 ст. 193 УК РФ). В соответствии с примечанием к данной статье указанные деяния признаются совершенными в крупном размере, если сумма незачисленных или невозвращенных денежных средств в иностранной валюте или валюте Российской Федерации по однократно либо по неоднократно в течение одного года проведенным валютным операциям превышает 9 млн р. Таким образом, размер нерепатриированных денежных средств определяется исходя из суммы всех контрактов, исполнение по которым наступило в течение года.

Квалифицированные составы рассматриваемого преступления связаны с совершением преступления группой лиц по предварительному сговору (ч. 1.1 ст. 193 УК РФ), в особо крупном размере (сумма невозвращенных денежных средств превышает 45 млн р.) (п. «а» ч. 2 ст. 193 УК РФ), организованной группой (п. «б» ч. 2 ст. 193 УК РФ), с использованием заведомо подложного документа (п. «В» ч. 2 ст. 193 УК РФ), с использованием юридического лица, созданного для совершения одного или нескольких преступлений, связанных с проведением финансовых операций и других сделок с денежными средствами или иным имуществом (п. «г» ч. 2 ст. 193 УК РФ).

Относительно преступления, установленного ст. 187 УК РФ, отметим, что действующим финансовым законодательством не закрепляется понятие «средства платежей». Данный термин не следует путать с другим понятием - «платежное средство». Анализ положений рассматриваемой статьи показывает, что предметом преступления («средствами платежей») являются поддельные платежные карты, распоряжения о переводе денежных средств, документы или средства оплаты, а также электронные средства, электронные носители информации, технические устройства, компьютерные программы, предназначенные для неправомерного осуществления приема, выда-

18 Собрание законодательства РФ. 2003. № 50 . Ст. 4859. чи, перевода денежных средств. Такие указанные предметы:

- различаются по своему материальному носителю (бумажный, пластиковый, электронно-цифровой);

- имеют различную природу и предназначение (платежные карты - расчетный инструмент, обеспечивающий доступ лица к счету, а также распоряжение денежными средствами; распоряжения о переводе денежных средств указание плательщика обслуживающей его кредитной организации перевести денежные средства; электронные средства, компьютерные программы и т.д. - предназначены для передачи электронных сообщений, в том числе содержащих распоряжения о переводе денежных средств).

В свою очередь, под платежным средством следует понимать денежные знаки, используемые для осуществления платежей.

Необходимо подчеркнуть, что предметом преступления, закрепленного в ст. 187 УК РФ, являются платежные документы, которые не относятся к числу ценных бумаг ${ }^{19}$.

Следующей группой финансовых преступлений являются общественно опасные деяния в сфере налогообложения. Основополагающим актом, обеспечивающим единообразие правоприменения судами уголовного законодательства об ответственности за налоговые преступления, является постановление Пленума Верховного Суда Российской Федерации «О практике применения судами уголовного законодательства об ответственности за налоговые преступления» от 28 декабря 2006 г. № 64 ${ }^{20}$. По сути, Верховный Суд РФ вводит в обращение термин «налоговые преступления», в качестве которых следует трактовать деяния, запрет на совершение которых установлен:

- ст. 198 УК РФ («Уклонение от уплаты налогов и (или) сборов с физического лица»);

- ст. 199 УК РФ («Уклонение от уплаты налогов и (или) сборов с организации»);

- ст. 199.1 УК РФ («Неисполнение обязанностей налогового агента»);

- ст. 199.2 УК РФ («Сокрытие денежных средств либо имущества организации или индивидуального предпринимателя, за счет кото-

\footnotetext{
${ }^{19}$ Апелляционное определение Московского городского суда от 3 августа 2015 г. по делу № 10-9123/2015 // СПС «КонсультантПлюс».

${ }^{20}$ Бюллетень Верховного Суда РФ. 2007. № 3.
} 
рых должно производиться взыскание налогов и (или) сборов»).

Указанные преступления объединяет то, что: - их объектом являются общественные отношения, складывающиеся в процессе взимания налогов и (или) сборов, т.е. налоговые отношения. Указанные общественные отношения по своей природе являются финансовыми, поскольку налоги выступают в качестве одного из основных доходных источников формирования бюджетов бюджетной системы Российской Федерации;

- предметом преступлений являются налоги и (или) сборы - обязательные платежи, установленные законодательством о налогах и сборах и предназначенные для финансового обеспечения деятельности государства и муниципальных образований (налоги) и покрытия расходов, которые публично правовой субъект несет в связи с предоставлением юридически значимых действий в отношении плательщика и (или) осуществлением отдельных видов предпринимательской деятельности на территории муниципальных образований (сборы);

- субъектами преступлений являются участники налоговых правоотношений - налогоплательщики (плательщики сборов), а также налоговые агенты, правовой статус которых определяется налоговым законодательством. Указанные лица не выполняют возложенные на них обязанности по уплате законно установленных налогов и сборов, в результате чего они становятся преступниками;

- объективная сторона налоговых преступлений, как правило, характеризуется бездействием - уклонение от уплаты налогов и (или) сборов, неисполнение обязанностей налогового агента. Единственным исключением является объективная сторона преступления, предусмотренного в ст. 199.2 УК РФ, выражающегося в сокрытии денежных средств либо имущества организации или индивидуального предпринимателя, за счет которых в порядке, предусмотренном законодательством Российской Федерации о налогах и сборах, должно быть произведено взыскание недоимки по налогам и (или) сборам. В то же время указанные действия приводят к неуплате недоимок по налогам и сборам;

- уголовная ответственность за налоговые преступления наступает только в случае, если они совершаются в крупном размере; за правонарушения в меньшем размере субъекты нало- говых правоотношений привлекаются к налоговой ответственности.

Близким по своему содержанию к налоговым преступлениям является состав, закрепленный в ст. 194 УК РФ, предусматривающий ответственность за уклонение от уплаты таможенных платежей, взимаемых с организации или физического лица. В рассматриваемом случае ответственность также наступает за уклонение от уплаты обязательных фискальных платежей, совершаемое в крупном размере. Отличие заключается в том, что данное преступление совершается в особой сфере общественных отношений - таможенной.

Следует отметить, что, согласно п. 1 ст. 70 Таможенного кодекса Таможенного союза, к таможенным платежам относятся ввозная и вывозная таможенные пошлины, косвенные налоги - налог на добавленную стоимость и акцизы, а также таможенные сборы. Таким образом, уклонение от уплаты НДС и акцизов может быть квалифицировано как преступление по ст. 194 УК РФ или по ст. 198 и 199 УК РФ в зависимости от того, идет ли речь о внешнеэкономических или внутренних налогах.

Кроме того, вопрос о юридической природе таможенных пошлин в науке финансового права носит дискуссионный характер. Несмотря на то что действующим законодательством таможенная пошлина не отнесена к числу налоговых платежей, ряд ученых считает возможным рассматривать данный обязательный платеж в качестве косвенного налога [11, с. 113-130]. В связи с этим в зависимости от решения данного вопроса преступление, закрепленное в ст. 194 УК РФ, может быть отнесено к числу налоговых или же выделено в отдельную группу финансовых преступлений.

Подводя итог, можно прийти к выводу, что финансовые преступления представляют собой собирательную категорию, которая позволяет консолидировать различные виды общественно опасных деяний, совершаемых в области налогообложения, в бюджетной сфере, в процессе денежного обращения, оказания финансовых услуг и т.д. Общим объектом данных преступлений являются общественные отношения, возникающие в финансовой сфере, т.е. в процессе аккумулирования, распределения (перераспределения) и использования централизованных и децентрализованных публичных (государственных и муниципальных) денежных фондов, исполнения денежных обязанностей перед государством, оказания финансовых услуг фи- 
зическим лицам и организациям. Следовательно, финансовые преступления наносят ущерб стабильности финансовой системы государства, подрывают финансовую дисциплину, негативно влияют на развитие финансовой инфраструктуры Российской Федерации.

Криминологическая характеристика субъектов финансовых преступлений. Криминологические исследования в сфере финансовых преступлений позволяют заключить, что в качестве обвиняемых по таким уголовным делам проходят прежде всего должностные лица практически всех категорий и уровней.

Как уже говорилось, официальная статистика не выделяет финансовые преступления из состава экономических. В связи с этим полагаем, что выводы, характеризующие субъектов экономических преступлений, могут быть экстраполированы на лиц, совершающих финансовые преступления.

Говоря о гендерной принадлежности лиц, совершающих экономические преступления, следует отметить, что подавляющее их большинство составляют мужчины - 79 \%; женщины - всего 21 \%. Чаще всего экономические преступления совершают лица в возрасте от 30 до 49 лет - 48 \%. Интересно, что лица более старшего возраста менее склонны к совершению преступлений такого рода. Например, граждане в возрасте старше 50 лет совершают всего 7 \% таких преступлений. Также следует отметить, что чаще всего экономические преступления совершают жители городов - $92 \%$.

И наконец, в основе еще одной классификации заложена социально-ролевая характеристика лиц, которые совершили преступления в экономике (предполагается, что к этой градации относятся лица, как задействованные в преступной деятельности в экономической сфере, так и совершившие преступления против собственности):

- рабочие - 34,0\%;

- учащиеся - 6,0 \%;

- служащие - 5,0 \%;

- сотрудники частного сектора - 5,5 \%;

- лица, занятые в сельском хозяйстве, - 3,0\%;

- осужденные к наказанию в виде лишения свободы - 0,5 \%;

- иные $-4,0 \%$.

Если говорить о криминологическом портрете преступника, совершившего экономические преступления, то следует отметить, что это, как правило, лицо, имеющее достаток выше среднего, высокий уровень интеллектуального развития, достаточно высокий социальный статус, практический склад ума, высокую мотивацию к достижению успеха [12].

Отмечается, что бо́льшая часть финансовых преступников имеет высокий образовательный уровень. Приводятся следующие данные:

- высшее образование у 59,2 \% лиц;

- лица в возрасте от 30 до 49 лет (76,3 \%), что закономерно, поскольку именно в этом возрастном периоде большинство людей обладает необходимым жизненным и профессиональным опытом, занимает руководящие должности;

- в 60,0 \% случаях лица состоят в браке;

- судимость на момент совершения преступления отсутствовала у 88,2 \% преступников;

- чаще преступления совершаются в одиночку, однако достаточно высок процент преступлений, совершенных в группе (30,3 \%);

- лица, которым вменяется совершенное преступление, характеризовались положительно по месту работы и проживания.

Таким образом, финансовые преступления - сфера интеллектуальной деятельности, требующая от преступника знания основ экономики и финансового законодательства. Субъект финансовых преступлений, как правило, осуществляет свою деятельность целенаправленно, проведя должную подготовку. При совершении общественно опасного деяния преступник руководствуется исключительно корыстными мотивами: его деятельность направлена на сокрытие своих доходов, придание правомерного вида незаконно полученным денежным средствам и имуществу, неправомерное завладение чужими (в том числе бюджетными) денежными средствами и т.д. Кроме того, преступник отличается высоким уровнем правового нигилизма, отрицая, в частности, обоснованность права государства взимать законно установленные налоги, сборы и иные виды обязательных платежей, требовать возвращения денежных средств, причитающихся по внешнеэкономическому контракту, а также справедливость иных ограничений его права пользования своими денежными средствами.

Заключение. Обобщая проведенные ранее исследования, к базовым причинам и условиям преступлений в финансовой сфере можно отнести следующие:

- пробелы в отраслевом финансовом законодательстве (бюджетном, налоговом, валютном, банковском и пр.);

- пробелы в уголовном законодательстве по рассматриваемой категории составов; 
- сложность применения финансового законодательства;

- отставание темпов подзаконного нормотворчества от темпов законодательной деятельности;

- отсутствие социально-правового контроля за финансовой деятельностью государства и муниципальных образований;

- отсутствие жесткого внутриведомственного и других видов контроля, их недостаточно эффективная организация;

- медленное становление системы финансового контроля, которое не успевает за развитием финансового законодательства;

- несовершенство общего надзора со стороны органов прокуратуры.

Безусловно, что рассмотренные категории преступлений в финансовой сфере носят сложный, а главное, комплексный характер, предполагающий проведение исследований (желательно совместных) в области доктринального и законодательного регламентирования финансово-правовых норм, нашедших свое отражение в таких элементах, как бюджетное, налоговое законодательство, сферы денежного и валютного регулирования, банковской и страховой деятельности, рынка ценных бумаг, а также децентрализованных финансов.
В этой связи противодействие преступной деятельности в финансовой сфере должно реализовываться посредством применения комплекса мер политического, экономического, социального, организационного и правового характера. Лишь благодаря внедрению и последующему использованию указанного подхода, проведению коллективных фундаментальных и прикладных разработок возможно эффективное принятие норм, устанавливающих ответственность за нарушение финансового законодательства, которое в последнее время находится в тренде, а главное, грамотное применение составов при расследовании уголовных дел, имеющих финансовую направленность и отличающихся высоким уровнем сложности. Ведь в основе заложено отстаивание публичного интереса, возврата публичных денежных средств, а значит, интереса общественного.

Борьба с преступной деятельностью в сфере финансов требует применения многостороннего подхода, и генеральная линия в этом направлении за уголовно-правовыми механизмами [13-19] ${ }^{21}$. Привлечение к уголовной ответственности представляется эффективной мерой борьбы в сфере финансовой деятельности.

${ }^{21}$ The devil's in the intent: does 18 U.S.C. § 666 require proof of quid-pro-quo intent // Southwestern law review. 2012. Vol. 42. P. 230-261.

\section{СПИСОК ИСПОЛЬЗОВАННОЙ ЛИТЕРАТУРЫ}

1. Кондрат Е.Н. Правонарушения в финансовой сфере России. Угрозы финансовой безопасности и пути противодействия / Е.Н. Кондрат - М. : Форум, 2014. - 928 с.

2. Петросян О.Ш. Понятие и состояние преступности в сфере обеспечения финансовой безопасности государства / О.Ш. Петросян // Финансовое право. - 2010. - № 10. - С. 25-28.

3. Трунцевский Ю.В. Финансовая безопасность: понятие и виды финансовых преступлений / Ю.В. Трунцевский // Финансы: теория и практика. - 2007. - № 2. - С. 11-22.

4. Raines M. Aspects of Securitization of Future Cash Flows Under English and New York Law / M. Raines, G. Wong // Duke Journal of Comparative \& International Law. - 2002. - Vol. 12. - P. 453-464.

5. Хамаганова Л.Д. Об эффективности валютного регулирования и валютного контроля при проведении внешнеторговых операций в Российской Федерации / Л.Д. Хамаганова // Известия Иркутской государственной экономической академии. - 2010. - № 5 (73). - С. 123-126.

6. Yackee J.W. Political Risk and International Investment Law / J.W. Yackee // Duke Journal of Comparative \& International Law. - 2014. - Vol. 24. - P. 477-500.

7. Yianni A. De The Return of Capital Controls? / A. Yianni, C. De Vera // Law and Contemporary Problems. - 2010. Vol. 73. - P. 357-371.

8. Gordon R.K. Losing the War Against Dirty Money: Rethinking Global Standards on Preventing Money Laundering and Terrorism Financing / R.K. Gordon // Duke Journal of Comparative \& International Law. - 2011. - Vol. 21. - P. 503-566.

9. Емельянов А.С. Финансово-правовая ответственность / А.С. Емельянов, Н.Н. Черногор. - М. : Финансы и статистика, 2004. - 208 c.

10. Научно-практический комментарий к Уголовному кодексу Российской Федерации от 13 июня 1996 г. № 63-Ф3/ Н.А. Агешкина [и др.]. - Саратов : Ай Пи Эр Медиа, 2013. - 848 с.

11. Артемов Н.М. Финансово-правовое регулирование внешнеэкономической деятельности : учебник / Н.М. Артемов, А.А. Ситник, С.О. Шохин ; отв. ред. Е.Ю. Грачева. - 4-е изд., перераб. и доп. - М. : Проспект, 2015. - 368 с.

12. Петросян О.Ш. Уголовно-правовые и криминологические основы обеспечения финансовой безопасности государства : автореф дис. ... д-ра юрид. наук : 12.00.08 / О.Ш. Петросян. - М., 2011. - 43 с.

13. Boutros A.S. «Carbon Copy» Prosecutions: A Growing Anticorruption Phenomenon in a Shrinking World / A.S. Boutros, T.M. Funk // The University of Chicago Legal Forum. - 2012. - P. 259-298. 
14. Buell S.W. «White collar» crimes / S.W. Buell // Oxford Handbook of Criminal Law / eds M. Dubber, T. Hornle. - Oxford, 2014. - P. 837-861.

15. Funk T.M. Getting What They Pay For: The Far-Reaching Impact. Of the Dodd-Frank Act's 'Whistleblower Bounty' Incentives on FCPA Enforcement [Electronic resource] / T.M. Funk // White collar crime report. - 2010. - Vol. 5, № 19. - Mode of access: https://www.perkinscoie.com/images/content/2/2/v2/22172/comm-10-09-whitecollarcrimereport.pdf.

16. Green S.P. Public perceptions of white collar crime culpability: bribery, perjury, and fraud / S.P. Green, M.B. Kugler // Law and contemporary problems. - 2012. - Vol. 2. - P. 33-59.

17. Posadas A. Combating corruption under international law / A. Posadas // Duke Journal of Comparative \& International Law. - 2000. - Vol. 10. - P. 345-414.

18. Richman D. Federal white collar sentencing in the United States: a work in progress / D. Richman // Law and contemporary problems. - 2013. - Vol. 1. - P. 53-73.

19. Underkuffler L.S. Captured by Evil: The Idea of Corruption in Law Duke Law School 2005 / L.S. Underkuffler. - U.S. : Yale Univ. Press, 2013. -256 p.

\section{REFERENCES}

1. Kondrat E.N. Pravonarusheniya $v$ finansovoi sfere Rossii. Ugrozy finansovoi bezopasnosti i puti protivodeistviya [Crimes in Russian Financial Sphere. Threats to Financial Safety and Ways of Counteraction]. Moscow, Forum Publ., 2014. 928 p.

2. Petrosyan O.Sh. The concept and condition of criminality in the sphere of the financial security of the state. Finansovoe pravo = Financial Law, 2010, no. 10, pp. 25-28. (In Russian).

3. Truntsevsky Yu.V. Financial Security: the Notion and Types of Financial Crime. Vestnik finansovoi akademii = Vestnik of the Finance Academy, 2007, no. 2, pp. 11-22. (In Russian).

4. Raines M., Wong G. Aspects of Securitization of Future Cash Flows Under English and New York Law. Duke Journal of Comparative \& International Law, 2002, vol. 12, pp. 453-464.

5. Khamaganova L.D. About the efficiency of currency regulation and currency control over foreign trade transaction in the Russian Federation. Izvestiya Irkutskoi gosudarstvennoi ekonomicheskoi akademii = Izvestiya of Irkutsk State Economics Academy, 2010, no. 5 (73), pp. 123-126. (In Russian).

6. Yackee J.W. Political Risk and International Investment Law. Duke Journal of Comparative \& International Law, 2014, vol. 24, pp. 477-500.

7. Yianni A., Vera C. De. The Return of Capital Controls? Law and Contemporary Problems, 2010, vol. 73, pp. 357-371.

8. Gordon R.K. Losing the War Against Dirty Money: Rethinking Global Standards on Preventing Money Laundering and Terrorism Financing. Duke Journal of Comparative \& International Law, 2011, vol. 21, pp. 503-566.

9. Emelyanov A.S., Chernogor N.N. Finansovo-pravovaya otvetstvennost' [Financial and Legal Liability]. Moscow, Finansy i Statistika Publ., 2004. 208 p.

10. Ageshkina N.A., Belyaev M.A., Belyaninova Yu.V., Biryukova T.A., Boldyrev S.A. Nauchno-prakticheskii kommentarii $k$ Ugolovnomu kodeksu Rossiiskoi Federatsii ot 13 iyunya 1996 g. № 63-Ф3 [Research and Practice Comment to the Criminal Code of the Russian Federation of June 13, 1996 № 63-Ф3]. Saratov, I.P.R. Media Publ., 2013. 848 p.

11. Artemov N.M., Sitnik A.A., Shokhin S.O.; Gracheva E.Yu. (ed.). Finansovo-pravovoe regulirovanie vneshneekonomicheskoi deyatel'nosti [Financial and Legal Regulation of Foreign Trade]. $4^{\text {th }}$ ed. Moscow, Prospekt Publ., 2015. 368 p.

12. Petrosyan O.Sh. Ugolovno-pravovye i kriminologicheskie osnovy obespecheniya finansovoi bezopasnosti gosudarstva. Avtoref. Dokt. Diss. [Criminal law and criminological basis of the financial security of the state. Doct. Diss. Thesis]. Moscow, 2011. $43 \mathrm{p}$.

13. Boutros A.S., Funk T.M. «Carbon Copy» Prosecutions: A Growing Anticorruption Phenomenon in a Shrinking World. The University of Chicago Legal Forum, 2012, pp. 259-298.

14. Buell S.W. "White collar» crimes. In Dubber M., Hornle T. (eds). Oxford Handbook of Criminal Law. Oxford, 2014, pp. 837-861.

15. Funk T.M. Getting What They Pay For: The Far-Reaching Impact. Of the Dodd-Frank Act's 'Whistleblower Bounty' Incentives on FCPA Enforcement. White collar crime report, 2010, vol. 5, no. 19. Available at: https://www.perkinscoie.com/images/content/2/2/v2/22172/comm-10-09-whitecollarcrimereport.pdf.

16. Green S.P., Kugler M.B. Public perceptions of white collar crime culpability: bribery, perjury, and fraud. Law and Contemporary Problems, 2012, vol. 2, pp. 33-59.

17. Posadas A. Combating corruption under international law. Duke Journal of Comparative \& International Law, 2000, vol. 10 , pp. 345-414.

18. Richman D. Federal white collar sentencing in the United States: a work in progress. Law and contemporary problems, 2013, vol. 1, pp. 53-73. $256 \mathrm{p}$.

19. Underkuffler L.S. Captured by Evil: The Idea of Corruption in Law Duke Law School 2005. U.S., Yale University Press, 2013.

\section{ИНФОРМАЦИЯ ОБ АВТОРАХ}

Артемов Николай Михайлович - заместитель заведующего кафедрой финансового права Московского государственного юридического университета им. О.Е. Кутафина (МГЮА), доктор юридических наук, профессор, г. Москва, Российская Федерация; e-mail: nikoarte@yandex.ru.

\section{INFORMATION ABOUT THE AUTHORS}

Artemov, Nikolai M. - Deputy Head, Chair of Financial Law, Kutafin Moscow State Law University (MSAL), Doctor of Law, Professor, Moscow, the Russian Federation; e-mail: nikoarte@yandex.ru. 
Арзуманова Лана Львовна - профессор кафедры финансового права Московского государственного юридического университета им. О.Е. Кутафина (МГЮА), доктор юридических наук, доцент, г. Москва, Российская Федерация; e-mail: Ilarzumanova@yandex.ru.

Болтинова Ольга Викторовна - заместитель заведующего кафедрой финансового права Московского государственного юридического университета им. О.Е. Кутафина (МГЮА), доктор юридических наук, профессор, г. Москва, Российская Федерация; e-mail: o.boltinova@mail.ru.

Саламова Себила Якубовна - старший преподаватель кафедры криминологии и уголовно-исполнительного права Московского государственного юридического университета им. О.Е. Кутафина (МГЮА), кандидат юридических наук, г. Москва, Российская Федерация; е-mail: sebila@mail.ru.

Ситник Александр Александрович - доцент кафедры финансового права Московского государственного юридического университета им. О.Е. Кутафина (МГЮА), кандидат юридических наук, доцент, г. Москва, Российская Федерация; e-mail: assitnik@gmail.com.

Чо Ын Джин - соискатель кафедры финансового права Московского государственного юридического университета им. О.Е. Кутафина (МГЮА), г. Москва, Российская Федерация; e-mail: choej@mail.ru.

\section{ДЛЯ ЦИТИРОВАНИЯ}

Артемов Н.М. Ответственность за нарушение финансового законодательства: уголовно-правовая и криминологическая характеристики преступлений, совершаемых в финансовой сфере / Н.М. Артемов, Л.Л. Арзуманова, О.В. Болтинова, С.Я. Саламова, А.А. Ситник, Чо Ын Джин // Всероссийский криминологический журнал. - 2017. T. 11, № 4. - C. 717-730. - DOI: 10.17150/25004255.2017.11(4).717-730.
Arzumanova, Lana L. - Professor, Chair of Financial Law, Kutafin Moscow State Law University (MSAL), Doctor of Law, Ass. Professor, Moscow, the Russian Federation; e-mail: llarzumanova@yandex.ru.

Boltinova, Olga V. - Deputy Head, Chair of Financial Law, Kutafin Moscow State Law University (MSAL), Doctor of Law, Professor, Moscow, the Russian Federation; e-mail: o.boltinova@mail.ru.

Salamova, Sebila Ya. - Senior Lecturer, Chair of Criminology and Penitentiary Law, Kutafin Moscow State Law University (MSAL), Ph.D. in Law, Moscow, the Russian Federation; e-mail: sebila@mail.ru.

Sitnik, Aleksandr A. - Ass. Professor, Chair of Financial Law, Kutafin Moscow State Law University (MSAL), Ph.D. in Law, Ass. Professor, Moscow, the Russian Federation; email: assitnik@gmail.com.

Cho Eun Jin - Ph.D. Student, Chair of Financial Law, Kutafin Moscow State Law University (MSAL), Moscow, the Russian Federation; e-mail: choej@mail.ru.

\section{FOR CITATION}

Artemov N.M., Arzumanova L.L., Boltinova O.V., Salamova S.Ya., Sitnik A.A., Cho Eun Jin. Liability for violating financial legislation: criminal law and criminological characteristics of financial crimes. Vserossiiskii kriminologicheskil zhurnal = Russian Journal of Criminology, 2017, vol. 11, no. 4, pp. 717-730. DOI: 10.17150/2500-4255.2017.11(4).717-730. (In Russian). 